\title{
Caecilia, Calpurnia, and Their Dreams of Political Importance. Patterns of Constructing Gender Relations and Female Scope for Action in Ancient Roman Sources
}

\author{
By Anna Katharina Romund ${ }^{*}$
}

\begin{abstract}
During the crisis of the Roman Republic, ancient sources mention a number of political interventions by women. The paper at hand seeks to investigate two of these occurences in which dreams motivated women to play an active role in political affairs. Cicero and Julius Obsequens report the dream of Caecilia Metella that instigated the repair of the temple of Juno Sospita in 90 BC. Nicolaus of Damascus, Velleius Paterculus, Valerius Maximus, Plutarch, Suetonius, Appian, Cassius Dio, and, again, Obsequens cover the dream of Caesar's wife Calpurnia in their works. According to them, the dream drove her to save Caesar from the imminent assassination in 44 BC. If we aim for a better understanding of the growing female scope for action, we will need to systematically analyse ancient authors' personal conceptions of gender relations in a comparative way. Therefore, my paper examines the reports on Caecilia and Calpurnia in order to find recurring patterns that reflect the writers' ideas of gender relations and gender hierarchies. A three-step analysis scheme will be created. 1) The model regards family roles as an indicator of the gender relationship discussed by the author. 2) The verbal or non-verbal mode of the woman's intervention, whether of strong or weak intensity, mirrors the options of female action depending on that specific relationship. Furthermore, this relationship is defined by means of the depicted reaction attributed to the addressee. 3) The reactions of the contemporaries or authorial commentaries display the author's attitude towards the female intervention. In addition, an ascription of affective emotions to the intervening woman correlates with a writer's disapproval.
\end{abstract}

\section{Introduction}

According to Cicero and Julius Obsequens, it was a dream of Caecilia Metella that motivated the Senate to restore the temple of Juno Sospita in 90 BC. ${ }^{1}$ Caecilia's intervention touches the sphere of religion where women, especially matrons, were permitted to exercise several rites. ${ }^{2}$ As the historical

\footnotetext{
* PhD Student, Research Associate, University of Osnabrück, Germany.

1. The sources are Cic. div. 1.4, 1.99, 2.136 (the latter without any hint to the repair); Obs. 55.
}

2. Cf. M.-L. Hänninen, "The Dream of Caecilia Metella. Aspects of Inspiration and Authority in Late Republican Roman Religion," in Female Networks and the Public Sphere in Roman Society, ed. by P. Setälä and L. Savunen (Rome: Institutum Romanum Finlandiae, 1999), 29; R.S. Kraemer, Her Share of the Blessings. Women's Religions among Pagans, Jews, and Christians in the Greco-Roman World (Oxford: Oxford Univ. Press 1992), 50-70; S.A. Takács, Vestal Virgins, Sibyls, and Matrons. Women in Roman Religion (Austin: Univ. of Texas Press, 2008), 91f.; J. Scheid, An Introduction to Roman Religion, transl. by J. Lloyd (Edinburgh: Edinburgh Univ. Press, 2003), 131f.; J.B. Rives, Religion in the Roman Empire (Malden: Blackwell Publishing, 2007), 33f., 117-121; V. Rosenberger, Gezähmte Götter. Das Prodigienwesen der römischen Republik [Tamed Gods. The Prodigy Process of in Republican Rome], Heidelberger Althistorische Beiträge und epigraphische Studien 27 (Stuttgart: Steiner, 1998), 171. The meaning of Juno Sospita is controversially discussed. Positions vary from 
background of the Marsian War makes clear, the restoration of the temple was not a mere ritual act but significant ad rem publicam. ${ }^{3}$ The circumstances of Caesar's death provide another occasion of an interfering woman. In 44 BC, the night before the Ides of March, Caesar's wife Calpurnia is said to have dreamed of her husband's assassination. Most historians of the imperial period report this story. ${ }^{4}$ Several of them claim that Calpurnia tried to convince Caesar of not attending the next day's Senate's assembly. Although the meeting took place in the Theater of Pompey during the Feriae Annae Perennae, ${ }^{5}$ I regard it as a regular session of the Senate since "[b]asically any public building could serve as curia if the auspices could be consulted from there these could take place". ${ }^{6}$ The only days in which the council was not allowed to assemble were the dies comitiales. ${ }^{7}$ As Höcker states, the Theater of Pompey was chosen as curia quite frequently in the years before Caesar's death. ${ }^{8}$ By using the word curia, Valerius Maximus makes clear that he considers this event to be a regular meeting of the Senate. ${ }^{9}$ Therefore, a political meaning has to be attributed to Calpurnia as well. Yet, Caesar attended and was murdered. In contrast to Caecilia, Calpurnia did not actually achieve her goal. In any case, Roman authors place great emphasis on women that appear as interfering figures in political affairs.

Scholars observed an accumulation of such interventions in sources dealing with the crisis of the Roman Republic and concluded that female agency increased during that period. ${ }^{10}$ Dixon, however, emphasises the influence of

references to fertility and marriage (cf. A. Mastrocinque, Bona Dea and the Cults of Roman Women, Potsdamer Altertumswissenschaftliche Beiträge 49 (Stuttgart: Steiner, 2014), 105; C. Schultz, "Juno Sospita and Roman Insecurity in the Social War," in Religion in Republican Italy, ed. by C.E. Schultz and P.B. Harvey (Cambridge: Cambridge Univ. Press, 2001), 207, 216-219; H.H. Scullard, Festivals and Ceremonies of the Roman Republic (Ithaka : Cornell Univ. Press, 1981), 70f.) to significance in war (cf. Hänninen, "Caecilia Metella", 35f.; Schultz, "Juno Sospita", 209, 221, 227).

3. Cic. div. 1.4: "to concern the administration of public affairs" (ad rem publicam pertinere); cf. Schultz, "Juno Sospita", 207, 227. According to Cic. div. 1.99, the occasion took place Marsico bello. Caecilia's dream is an example of prophecies being believed in bello multo etiam magis, quo maius erat certamen et discrimen salutis (div. 1.99). Obsequens mentions the context as follows: ubique in Latio clades accepta (Obs. 55).

4. Cf. P. Kragelund, "Dreams, Religion, and Politics in Republican Rome," Historia 50, no. 1 (2001), 53-95, 55. The sources are Nik. Dam. Aug. = FGrHist 90 F 130 § 83f.; Vell. 2.57.2; Val. Max. 1.7.2; Plut. Caes. 63.8-12; Suet. Iul. 81.3f.; App. civ. 2.115; Dio 44.17.2; Obs. 67.

5. Cf. F. Graf, "Anna Perenna," in Brill's New Pauly, Antiquity volumes, ed. by H. Cancik and H. Schneider, http://dx.doi.org/10.1163/1574-9347_bnp_e122270.

6. W. Eder, "Curia," in Brill's New Pauly, Antiquity volumes, ed. by H. Cancik and H. Schneider, http://dx.doi.org/10.1163/1574-9347_bnp_e12220940.

7. Cf. W. Kierdorf, "Senatus," in Brill's New Pauly, Antiquity volumes, ed. by H. Cancik and H. Schneider. http://dx.doi.org/10.1163/1574-9347_bnp_e1108330.

8. Cf. Höcker, C. "Theatrum Pompei(i)," in Brill's New Pauly, Antiquity volumes, ed. by H. Cancik and H. Schneider. http://dx.doi.org/10.1163/1574-9347_bnp_e1207070.

9. Val. Max. 1.7.2: ut proximo die curia se abstineret.

10. Cf. for example M.H. Dettenhofer, "Frauen in politischen Krisen. Zwischen Republik und Prinzipat" ["Women in Political Crises. Between Republic and Principate"], in Reine Männersache? Frauen in Männerdomänen der antiken Welt, ed. by M.H. Dettenhofer (Cologne: Böhlau, 1994), 133-157; J.K. Evans, War, Women and Children in Ancient Rome (London: Routledge, 1991); Kraemer, Her Share; B. Kreck, Untersuchungen zur politischen und sozialen 
contemporary discourse and genre on the portrayal by ancient male authors. ${ }^{11}$ The author's personal attitude towards gender roles must be taken into account more strongly than it has been so far. Späth and Treggiari, followed by others, made innovative approaches; ${ }^{12}$ but still, there is a lack of systematic access for instance regarding the comparison of different writers. ${ }^{13}$ Allegedly "insignificant" ${ }^{14}$ interventions remained a marginal note in gender studies. For example, there are only two papers discussing Caecilia in detail. ${ }^{15}$ Beyond that, there are only some smaller references to Caecilia and Calpurnia, ${ }^{16}$ although the two stories show that dreams as divine directives represent a situation that could have induced, if not even legitimated, female political agency in critical situations. ${ }^{17}$

On the other hand, in ancient studies on prodigy and dream, the cases of Caecilia and Calpurnia have already been the subject of debate in various respects. ${ }^{18}$ Some reference points to gender issues can be seen. According to

Rolle der Frau in der späten römischen Republik [Studies on Women's Political and Social Role in the Late Roman Republic] (Marburg, 1975); S. Fischler, "Social Stereotypes and Historical Analysis: The Case of the Imperial Women at Rome," in Women in Ancient Societies. 'An Illusion of the Night', ed. by L.J. Archer, S. Fischler, and M. Wyke (Basingstoke: Macmillan, 1994), 115-133.

11. Cf. S.A. Dixon, Reading Roman Women: Sources, Genres, and Real Life (London: Duckworth, 2007), ix, xi, xiv, 3-25.

12. Cf. T. Späth, Männlichkeit und Weiblichkeit bei Tacitus. Zur Konstruktion der Geschlechter in der römischen Kaiserzeit [Masculinity and Femininity in Tacitus. Constructing Gender in the Roman Empire], Geschichte und Geschlechter 9 (Frankfurt: Campus-Verlag, 1994); S. Treggiari, Terentia, Tullia und Publilia: The Women of Cicero's Family (London: Routledge, 2007).

13. Cf. Dixon, Reading Roman Women, 3-5.

14. Hänninen, "Caecilia Metella", 29.

15. Both articles deal with Caecilia's dream. Hänninen, "Caecilia Metella" discusses women's roles in Roman religion and regards the interest Caecilia's family had using her dream to stress their claims to power. Calpurnia's dream is mentioned (ibid., 34) but without going into detail. Schultz, "Juno Sospita", states the omission of the case of Caecilia in treatises on the Social War and emphasises the political significance of the Juno Sospita cult.

16. Various publications on Roman religion refer briefly to Caecilia's dream, but without reference to gender aspects; cf. Mastrocinque, Bona Dea, 104f.; Scullard, Festivals, 71. Calpurnia's vision is talked about apart from gender studies by D. Wardle, "The Sainted Julius: Valerius Maximus and the Dictator," CPh 92, no. 4 (1997), 323-345, 336.

17. Cf. C. Walde, "Explorationen: Schlaf - Traum - Traumdeutung und Gender in der griechisch-römischen Antike" ["Explorations: Sleep - Dream - Dream Interpretation and Gender in Greco-Roman Antiquity"], in Gender Studies in den Altertumswissenschaften: Schlaf und Traum, ed. by C. Walde and G. Wöhrle, 1-40, IPHIS 6 (Trier: Wissenschaftlicher Verlag Trier, 2014), 35, 37. Calpurnia is confronted with a threatening situation concerning her family in all sources but only Velleius Paterculus expresses this: futuri [...] periculi (Vell. 2.57.1); with regard to Caecilia, see this article, note 3 .

18. Cf. A. Corbeill, "Dreams and the Prodigy Process in Republican Rome," in Sub imagine somni: Nightmare Phenomena in Greco-Roman Culture, ed. by E. Scioli and C. Walde, 81-101 (Pisa: Ed. ETS, 2010), 92-95; W.V. Harris, "Roman Opinions about the Truthfulness of Dreams," JRS 93 (2003), 18-34, 26; W.V. Harris, Dreams and Experience in Classical Antiquity (Cambridge: Harvard Univ. Press, 2009), 104-107, 176; C. Pelling, "Tragical Dreamer: Some Dreams in the Roman Historians," $G \& R$ 44, no. 2 (1997), 197-213, 201; B. Scardigli, "Die Frau im Prodigienwesen der römischen Republik" ["Women in the Prodigy Process in Republican Rome"], in Egypte - Grèce - Rome. Les différents visages des femmes antiques; 
Rosenberger, Caecilia receives the divine sign because she is a woman and thus without power in state affairs. ${ }^{19}$ Kragelund also assesses Caecilia's act as exceptional on the basis of her $\operatorname{sex}^{20}$ and characterises Calpurnia as "a tragic heroine, a latter-day Cassandra" ${ }^{21}$ who symbolizes the fate of Caesar's house. Kragelund regards her story as an example for later sources that also picture the rise or fall of the principes via the representation of related women. ${ }^{22}$ Ripat generalizes from the case of Caecilia that socially lower people, such as women, were most likely to appear as "mere messengers, not recipients, of divine messages". ${ }^{23}$ Ripat explores the sources dealing with Caesar's murder and detects "general editorial patterns". ${ }^{24}$ Her approach is of great importance in view of the scarcely systematized analysis of female political interventions in gender studies. I wonder whether the dream episodes reveal recurring patterns that indicate the ancient author's opinion on gender roles. Answering this question, the following study aims at developing a methodology to highlight and compare the individual writer's ideal concerning relations between man and woman.

Walde identifies the connection between gender and dream as a trend of current research. ${ }^{25}$ Due to the fact that culture determines both aspects, she proclaims the potential of connecting gender and dream studies. ${ }^{26}$ Given this double construct character, one can expect that the accounts on Caecilia and Calpurnia display idealised gender roles. ${ }^{27}$ On the one hand, the episodes are comparable as in both cases a nightly vision triggers the female intervention. On the other hand, acknowledging the women's success, the accounts differ from each other. Already in 1901, Vaschide and Piéron point to variations between

travaux et colloques du séminaire d'épigraphie grecque et latine de l'IASA 2002-2006, ed. by F. Bertholet, A. Bielman Sanchez and R. Frei-Stolba, 197-221, Echo 7 (Bern: Peter Lang AG, 2008), 209; G. Weber, Kaiser, Träume und Visionen in Prinzipat und Spätantike [Emperors, Dreams and Visions in Principate and Late Antiquity], Historia. Einzelschriften 143 (Stuttgart: Steiner, 2000), 432-436. Even in some treaties that deal with dreams during the late Republic, the apparitions of Calpurnia and Caecilia are omitted; cf. E. Rawson, "Religion and Politics in the Late Second Century B.C. at Rome," Phoenix 28.2 (1974), 193-212.

19. Cf. Rosenberger, Gezähmte Götter, 225.

20. Kragelund, "Dreams", 60.

21. Ibid., 55.

22. Cf. ibid.

23. P. Ripat, "Roman Omens, Roman Audiences, and Roman History," G\&R 53, no. 2 (2006), 155-174, 160.

24. Ibid. 174; for a standardized construction of dream reports cf. also Corbeill, Dreams, 9295.

25. Cf. Walde, "Explorationen", 1f., 34f., 37; first approaches by Kraemer, Her Share, 58f.; S. MacAlister, "Gender as Sign and Symbolism in Artemidoros: Social Aspirations and Anxieties," Helios 19 (1992), 140-160, 145-155; Rosenberger, Gezähmte Götter, 170-175; A. Wardman, Religion and Statecraft among the Romans (Baltimore: JHU Press, 1982), 38f. A further developed concept is presented by E. Scioli, "The Dream Narrative as a Mode of Female Discourse in Epic Poetry," TAPhA 140, no. 1 (2010), 195-238.

26. Cf. Walde, "Explorationen", 1 (verbatim in German: "kulturell determiniert").

27. Cf. Fischler, "Stereotypes", 117-121. 
the reports on Calpurnia. ${ }^{28}$ Since this case provides a wide range of sources, it is perfectly suitable for exploring recurring design principles. The dream of Caecilia expands the spectrum of authors and facilitates independence from specific features determined by the narrative.

By developing a new methodology, this paper will focus on the sources at hand. ${ }^{29}$ My approach is based on discourse theory, assuming that all ancient authors contributed to the contemporary discourses in their texts and expressed their own attitude towards these discourses. ${ }^{30}$ Furthermore, since the emphasis lays on the structural elements that connect all accounts, the authors' historical and biographical backgrounds, although of great importance for their arrangement of the story, will be neglected. In order to find indicators of an ancient writer's attitude towards female influence, the current and prospective approach elucidates the individual author's representation of gender relations and reflects on the patterns used.

\section{The Intervention of Caecilia}

Caecilia's intervention is only preserved by two authors who wrote within a time interval of approximately 400 years. I will start by analysing Cicero's depiction of gender roles.

\section{Tullius Cicero (106 to 43 BC)}

In his De divinatione, Cicero discusses his personal idea of truthfulness of prophecies. ${ }^{31}$ Written in 45 or $44 \mathrm{BC},{ }^{32}$ his descriptions of Caecilia's dream represent the only Republican source for both interventions. Cicero mentions the portent in three paragraphs (Cic. div. 1.4, 1.99, and 2.136). ${ }^{33} \mathrm{He}$ deals with the restoration of the temple resulting from the dream in the first book only and does not report the content of the dream. Caecilia's intervention is almost

28. Cf. N. Vaschide, and H. Piéron, "Prophetic Dreams in Greek and Roman Antiquity," The Monist 11.2 (1901), 161-194, 177; likewise Kragelund, "Dreams", 55; Ripat, "Omens", 168172. With regard to differences in the sources for Caecilia, cf. Kragelund, "Dreams", 57-60.

29. In the long run, this literary approach provides an analytical frame for a PhD project at the University of Osnabrueck. My PhD thesis deals with political interventions of women. A widened research angle and the historical discussion about the female influence in the late Roman Republic will be part of the PhD thesis itself. Scioli, "Dream Narrative" has proved the potential of a literary approach. Her article contributed several ideas to the following investigation, fruitful are especially the chapters II, IV, VII and VIII.

30. Regarding Caecilia's dream, research discusses which account is to prefer rather than the assessment of every source on its own as an expression of the author's intention; cf. for example Schultz, "Juno Sospita", 221.

31. Cf. M. von Albrecht, Geschichte der römischen Literatur. Von Andronicus bis Boethius, mit Berücksichtigung ihrer Bedeutung für die Neuzeit [History of Roman Literature. From Andronicus to Boethius, Taking into Account Their Importance for Modern Times] 2 Vol., (Berlin: de Gruyter, 2012), vol. I, 448; L. Hermes, Traum und Traumdeutung in der Antike [Dream and Dream Interpretation in Antiquity] (Zurich: Artemis \& Winkler, 1996), $180 \mathrm{f}$.

32. Cf. Albrecht, Geschichte, I 448; Hänninen, "Caecilia Metella", 29.

33. Cf. F. Münzer, "Caecilius [135]," in RE III.1 (1897), 1235. 
invisible. The author merely writes that the Senate restored the temple "in accordance with a dream of Caecilia, daughter of Balearicus" (ex Caeciliae, Baliarici filiae, somnio; Cic. div. 1.4, very similar 1.99). ${ }^{34}$ His female protagonist must have externalized her vision so that she finally was listened to by the Senate. It seems likely that she did not talk to the Senate personally, but none of Cicero's texts reveals whether Caecilia spoke to the Senate herself or via intermediate instances. ${ }^{35}$ Due to the prominent placement of the words Caeciliae [...] filiae on the first (Cic. div. 1.99) and the final position of the sentence (Cic. div. 1.4), it must have been important to Cicero to stress the reason for the restoration. He clearly highlights the woman as the initiator ${ }^{36}-$ and clearly as filia.

The reference Baliarici filiae (Cic. div. 1.4, 2.136) respectively $Q$. filiae (Cic. div. 1.99) appears in all three texts. ${ }^{37}$ Scholars identified Balearicus as the consul of $123 \mathrm{BC},{ }^{38}$ a fact which is not attested in Cicero's text. Neither the scene itself nor the context of the textual passage attributes any additional function to Balearicus. According to Hallett, even married women were "symbolically [...] defined as daughters", 39 because the father represents a "metaphor of controlling". ${ }^{40}$ In view of Caecilia's political influence, this is a likely explanation for Cicero's report, but he may have had various reasons for referring to her father. ${ }^{41}$ The parallel threefold mention of the filiation is that striking that one has to raise the question why Cicero emphasises Caecilia's role as a filia, while, at the same time, attributing political influence to her. Therefore, I observe the family role as a possible design principle.

The player who carries out the restoration is not Caecilia herself but the consul L. Julius Caesar (Cic. div. 1.4) or the Senate (Cic. div. 1.99). ${ }^{42}$ Regarding the question of gender relation, it is self-evident to Cicero that men alone are responsible for public action. ${ }^{43}$ As he writes: L. Iulius, qui cum P. Rutilio

34. Cf. Hänninen, "Caecilia Metella", 29; Harris, Dreams, 176; Kragelund, "Dreams", 54; Ripat, "Omens", 160.

35. Cf. Hänninen, "Caecilia Metella", 30, 38; Kragelund, "Dreams", 57; Schultz, "Juno Sospita", 208.

36. Cf. Hänninen, "Caecilia Metella", 38.

37. The reference to a male family member becomes apparent due to the purpose of identifying Caecilia in the face of the Roman custom of naming women, cf. Dixon, Reading Roman Women, xf.; M.I. Finley, Aspects of Antiquity. Discoveries and Controversies (Harmondsworth: Penguin Books, 1978), 125f.

38. Cf. Hänninen, "Caecilia Metella", 30f.; Harris, "Roman Opinions", 26; Kragelund, "Dreams", 60f.; Ripat, "Omens", 160; Rosenberger, Gezähmte Götter, 225.

39. J.P. Hallett, Fathers and Daughters in Roman Society. Women and the Elite Family (Princeton: Princeton Univ. Press, 1984), 67.

40. Ibid.

41. Political reasons are claimed by Rosenberger, Gezähmte Götter, 225; regarding the aristocratic background, cf. also Hänninen, "Caecilia Metella", 31-33; Harris, Dreams, 176; Kragelund, "Dreams", 60-63; Schultz, "Juno Sospita", 207. Furthermore, Kragelund, "Dreams", 63 states personal reasons like Caecilia's "unmarried status". On the contrary, she is characterised as a matron by Hänninen, "Caecilia Metella", 37f.; Münzer, "Caecilius", 1235. However, Cicero's reason for choosing the father remains speculative.

42. Cf. Harris, "Roman Opinions", 26; Harris, Dreams, 176; Scullard, Festivals, 71.

43. Cf. Dettenhofer, "Frauen", 148f.; Schultz, "Juno Sospita", 223. 
consul fuit, de senatus sententia refecit (Cic. div. 1.4), L. Julius Caesar clearly is the subject of the sentence and his action is described more in detail than Caecilia's. He is introduced by a reference to his colleague Rutilius and by his public function as consul. Caecilia appears as filia by a reference to her father Balearicus and by her family role (Cic. div. 1.4). The complementary description of Caecilia and L. Julius appears exactly in the paragraph in which Cicero mentions the case as an example of the fact that: "Nor, indeed, were the more significant dreams, if they seemed to concern public affairs, disregarded by our Supreme Council." (Nec vero somnia graviora, si quae ad rem publicam pertinere visa sunt, a summo consilio neglecta sunt; Cic. div. 1.4). ${ }^{44}$ The second account does not refer to the res publica. Cicero merely names the Senate as an actor ( $a$ senatu, Cic. div. 1.99). Thus, in view of Caecilia's influence ad rem publicam, he emphasises the family as female sphere. ${ }^{45}$

Nonetheless, Cicero clearly ascribes the role of the initiator to Caecilia. He does so without any negative evaluation. Cicero even underlines the credibility of the dream by using the historian Sisenna as a reference. ${ }^{46}$ As already mentioned, the intervention is successful. This interpretation results from the Senate's - that is the final addressee's - positive reaction. Nothing reflects that Caecilia's initiative has crossed the "boundaries" 47 of the author's gender role ideal. ${ }^{48}$ On this condition, her contribution does not need to be concealed. Cicero's agreement to the woman's influence and her success are related to each other. In order to examine whether this is a recurring pattern, it is necessary to analyse the other accounts.

\section{Julius Obsequens $\left(2^{\text {nd }}\right.$ half of the $4^{\text {th }}$ Century AD)}

In Late Antiquity, Julius Obsequens recounts Caecilia's dream (Obs. 55, all subsequent quotations from this chapter). ${ }^{49}$ Scholars consider his Liber de prodigiis an extract from $A b$ urbe condita, but we cannot assume that this is a trustworthy copy of Livy's original. ${ }^{50}$ Contrary to Cicero, Obsequens informs

44. Cf. Harris, Dreams, 176; Kragelund, "Dreams", 54, 59; Schultz, "Juno Sospita", 221.

45. For similar considerations about male and female spheres in the course of a different topic, cf. Scioli, "Dream Narrative", 226. Hänninen, "Caecilia Metella", 35 states "the gender of the dreamers does not appear to have been important to Cicero". However, she refers to the credited trustworthiness.

46. Hänninen, "Caecilia Metella", 29; Kragelund, "Dreams", 54; Schultz, "Juno Sospita", 208. In div. 2,136, with a great textual distance, Cicero claims that the vision might be fictitious (cf. Hänninen, "Caecilia Metella", 29f.).

47. Scioli, "Dream Narrative", 219.

48. Cf. Fischler, "Stereotypes", 117-121; Kreck, Untersuchungen, 105; Scioli, "Dream Narrative", 217-219.

49. Cf. Münzer, "Caecilius", 1235; P.L. Schmidt, Iulius Obsequens und das Problem der Livius-Epitome. Ein Beitrag zur Geschichte der lateinischen Prodigienliteratur [Julius Obsequens and the Problem of the Livy Epitomes. A Contribution to the History of the Latin Literature on Prodigies], Abhandlungen der Geistes- und Sozialwissenschaftlichen Klasse 5 (Wiesbaden: Steiner, 1968), 161f., 229-235; Schultz, "Juno Sospita", 208.

50. Cf. Albrecht, Geschichte, II 1179; Schmidt, Iulius Obsequens, 217; Schultz, "Juno Sospita", 209, 221. In Kragelund's eyes, Obsequens is "preserving" the text of Livy, Kragelund, "Dreams", 54; cf. p. 55 note 7, 60, although he points to the differences between these two 
us about the content of the vision. ${ }^{51}$ Caecilia is said to have dreamed of the flight of the goddess Juno "because her temple had been badly dishonored" (quod immunde sua templa foedarentur). ${ }^{52}$ The vision itself contains a first action since Caecilia "with difficulty recalled the goddess pleadingly" (cum suis precibus aegre revocatam). The response by the addressee is positive so that the dream world intervention is successful. Caecilia's conduct, to the manner described, does not contradict Obsequens's concept of gender roles. Once again, success is connected to the acceptance of her influence by the author.

As a second intervention, Obsequens lets Caecilia recount the vision and restore the temple (Metella Caecilia [...] diceret, aedem [...] restituit). As every male protagonist of Cicero's portrayal is missing in Obsequens's account, the institution of the Senate is absent likewise. ${ }^{53}$ Since Rosenberger does not pay enough attention to the differences within the sources, he is able to claim that Caecilia's intervention needed a "Placet" ${ }^{54}$ of the Senate. ${ }^{55}$ While Cicero does not mention any action personally carried out by this woman, in Obsequens's report it is the Senate that does not play any role. In the beginning, one can read the phrase L. Iulio Caesare P. Rutilio coss., but this only refers to the year of the occurrence as it does throughout the whole Liber de prodigiis. A man is mentioned only in the second part of the chapter ${ }^{56}$ subsequent to the report on Caecilia's intervention. Being the subject of the sentence, she is the sole actor. She repairs the temple on her own. ${ }^{57}$ Compared to Cicero, Obsequens admits significantly more space for a manoeuvre to the woman. He also mirrors that scope for action by two extended hyperbata (Metella Caecilia [...] diceret, aedem [...] restituit). Finley states that, during the Republic, there was only a small scope for female action in religion. Obsequens, thus, seems to have reflected the circumstances of his lifetime in the episode. ${ }^{58}$

Looking at the manners of operating more precisely, there is a mere verbal action in the dream intervention: "recalled the goddess pleadingly" (precibus [...] revocatam). Scioli argues for considering the "mode of communication". ${ }^{59}$ In the waking-world, on the one hand, Caecilia also intervenes verbally, though no longer pleading now: The verb diceret expresses the first of two operations. Obsequens provides a late antique figuration of Caecilia's dream which Cicero has not mentioned, but we do not learn about the addressee at this point. On the

authors; cf. p. 60 note 21. English translation of Obsequens's passages: A.K.R., sometimes closely following Schultz, "Juno Sospita", 208.

51. Cf. Kragelund, "Dreams", 57.

52. Cf. Scardigli, "Frau im Prodigienwesen", 209.

53. Cf. Kragelund, "Dreams", 60; Schultz, "Juno Sospita", 221.

54. Rosenberger, Gezähmte Götter, 225. He states that asking for the Senate's decision was necessary because the distinction by means of being an addressee of the gods ran contrary to the collective thought of the res publica; cf. also Ripat, "Omens", 159.

55. A confusion of the two versions is also to be found in Scullard, Festivals, 71; cf. Schultz, "Juno Sospita", 208.

56. Cf. Kragelund, "Dreams", 57.

57. Cf. ibid., 60.

58. Cf. Finley, Aspects, 133.

59. Scioli, "Dream Narrative", 208. 
other hand, by using the word restituit, Obsequens ascribes a "non-verbal"60 action to the female protagonist. In his text, the relationship between Caecilia and the goddess concerning the verbal action is strictly hierarchical. Regarding the more insistent verbal and the non-verbal intervention, no subordinate relationship to an addressee is given. In result, the mode of operating is an evident indicator of the woman's hierarchical position in regard to her addressee and in regard to the accompanying repertoire of action.

Caecilia's waking-world intervention is likewise successful as the results indicate: She "restored the temple to its previous splendour" (aedem [...] pristino splendore restituit). By using the word splendore, the action is positively connoted. Again, there is a link between success and agreement with the female interference. Obsequens emphasises the acceptance even more than Cicero: He mentions matrons (matronarum) that had tarnished the temple "by dirty and shameless bodily activities" (sordidis obscenisque corporis coinquinatum ministeriis). ${ }^{61}$ Whereas they caused the escape of the goddess, Caecilia embodies the devout and dutiful counterexample. ${ }^{62}$ Caecilia's "virtues" ${ }^{63}$ made the temple shine again. Julius Obsequens's report allows such a characterisation of Caecilia, whereas Münzer, Hänninen, Kragelund, and Ripat foreground her virtue by identifying her as the woman mentioned in Pro Roscio - an assumption which is highly speculative. ${ }^{64}$ Obsequens deals with the conduct of matrons rather than with relations between man and woman. That preference explains the omission of all male protagonists. Remarkably, he does not present Metella Caecilia as filia but refers to her gens only. ${ }^{65}$ The family role is left out while female behaviour is discussed. Thus, the reference to a certain role identifies the particular gender relationship the author comments on.

\section{Interim Conclusion}

The current paper seeks to find recurring patterns for expressing an ancient author's gender discourse. Having compared the two accounts on Caecilia, first conclusions can be drawn. As we have seen, the role of the family indicates the particular gender relations or gender role the author makes a statement on.

60. Ibid.

61. Cf. Hänninen, "Caecilia Metella", 36-38; Kragelund, "Dreams", 59; Scardigli, "Frau im Prodigienwesen", 209; Schultz, "Juno Sospita", 221. Scholars discuss whether Obsequens talks about illicit sexual relations or a misuse of the temple as public toilettes; cf. Hänninen, "Caecilia Metella", 30; Schultz, "Juno Sospita", 208. 160.

62. Cf. Hänninen, "Caecilia Metella", 37; Kragelund, "Dreams", 60, 63f.; Ripat, "Omens",

63. Hänninen, "Caecilia Metella", 38. Cf. Kragelund, "Dreams", 63: "virtus".

64. Cf. Hänninen, "Caecilia Metella", 32, 37f.; Münzer, "Caecilius", 1235; Kragelund, "Dreams", 60f., 63f.; Ripat, "Omens", 160. They refer to Cic. Rosc. 27, 147, 149. Regarding the virtuous ideal of a matron in general, cf. Fischler, "Stereotypes", 117-121.

65. Cf. Kragelund, "Dreams", 60. 
There are obviously two different modes of action, verbal and nonverbal, ${ }^{66}$ mirroring the hierarchical grading between the female intervener and the male or female addressee. The mere verbal intervention appears when Caecilia's influence is directed to the Senate as the summum consilium and to the goddess Juno. The mode of action is, therefore, regarded as an indicator of a significantly subordinate position to the addressee. It reflects the correspondingly limited options of acting. A non-verbal intervention argues for a revalued position to the addressee in view of which a greater space of operating is available to the woman.

A low female position does not equal ineffectiveness. The opposite is the case: Cicero's Caecilia influences the Senate. In Obsequens's description she even persuades a goddess to return. The attribution of success, apparent in the positive response of the addressee, is accompanied by the author's acceptance of the female intervention. For this reason, the questions arise whether a woman is only depicted successful if her influence is accepted by the author and whether she is always credited with achievement if this is the case. In this respect, success and failure would be indicators of the author's attitude towards the intervention.

\section{The Intervention of Calpurnia}

To examine the thesis of the modes, the following chapter investigates the accounts of Calpurnia's unsuccessful intervention. ${ }^{67}$ All authors make her act within the family role of a yvvì respectively an uxor. They define her with reference to Caesar who is mostly but not entirely in the focus of the narrative. Valerius Maximus, though speaking about Augustus, also presents Calpurnia as divi Iuli patris sui uxorem Calpurniam (Val. Max. 1.7.2). Thus, all statements refer to the relationship between husband and wife.

66. Cf. Scioli, "Dream Narrative", 208.

67. Cicero lists various omens of the murder but does not mention Calpurnia (Cic. div. 1.119; 2.23; 2.36f.; 2.52). Plutarch hands down the version of Livy (Plut. Caes. 63.9f.; cf. Kragelund, "Dreams" 55; Vaschide and Piéron, "Prophetic Dreams", 177; Weber, Kaiser, 434). After describing the content of the dream, the intervention is told but it is not clear whether the report about Calpurnia's reaction belonged to this version of Livy, too, nor do we know how far Plutarch had changed the account of his predecessor at this point. 
Nicolaus of Damascus (64 BC to Time of Augustus)

The Augustan historian Nicolaus of Damascus (Nik. Dam. Aug., FGrHist 90

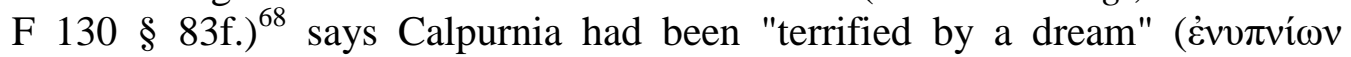
$\delta \varepsilon 1 \mu \alpha \tau \omega \theta \varepsilon \bar{i} \sigma \alpha, \S 83)$ and therefore "clung to him [Caesar] and said that she

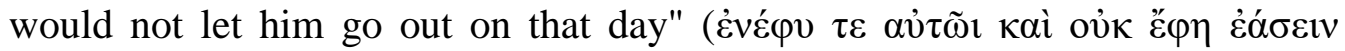

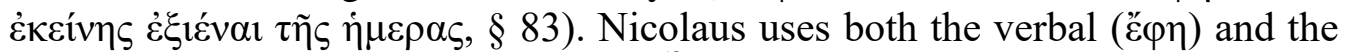

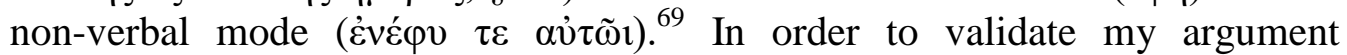
concerning the modes, we would need to see Calpurnia having larger scope for action in her conjugal relationship with Caesar. And indeed, according to Nicolaus, Caesar's friends and others tried to keep Caesar from going to the

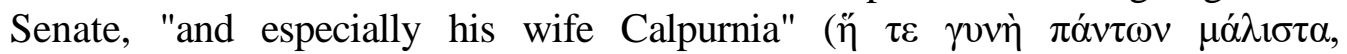

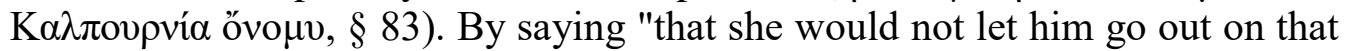

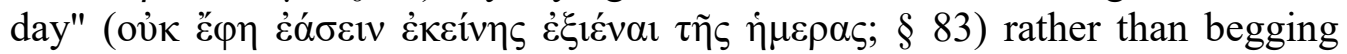
Caesar to stay at home, as in the other reports on Calpurnia, she acts very emphatically. Compared to these reports, the verbe $\tilde{\varepsilon} \varphi \eta$ reveals that there are different degrees regarding the intensity of the verbal mode of intervention: saying is of stronger quality than begging. Hence, a revaluated position against Caesar is discernible and therefore underpins the hypothesis about non-verbal actions. A closer look on the non-verbal mode in the stories of Obsequens and Nicolaus, however, elucidates different intensities of intervention. Obsequens's Caecilia takes an active creative role (restituit, Obs. 55) whereas Nicolaus's

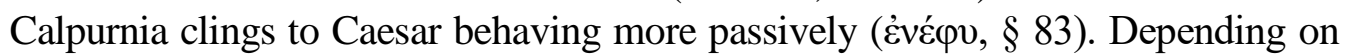
her non-verbal and her insistent verbal intervention, Nicolaus's Calpurnia has a large scope for action compared to the female protagonists to be dealt with later. Nonetheless, Calpurnia cannot act as independently as Caecilia in her wake-world intervention. Caecilia does not even have any addressee. My argument, therefore, has to be modified in a way that there is a strong and a weak quality in both modes reflecting the hierarchical position against the addressee.

Caesar's reaction remains invisible in Nicolaus's report which gives even more weight to the female act. The man's response is only implicitly included. Brutus supposedly mocked Caesar by saying: "Are you going to pay any attention

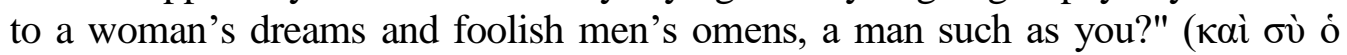

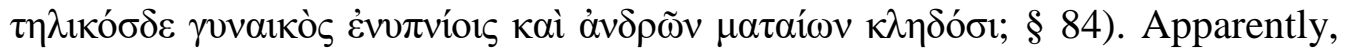
Caesar announced his absence from the Senate session - "using 'the dreams of a woman' as his excuse". ${ }^{70}$ This is remarkable. Although she could not succeed in view of the outcome of the story, Calpurnia is temporarily granted success. Using the modes and the positive reaction of the addressee, the author, firstly, constructs a great influence of the wife on her husband. Secondly, since this is

68. Cf. Kragelund, "Dreams", 55 note 7; Harris, Dreams, 91; K. Meister, "Nicolaus [3]," in Brill's New Pauly, Antiquity volumes, ed. by H. Cancik and H. Schneider, http://dx.doi. org/10.1163/1574-9347_bnp_e822620.

69. Cf. LSJ: A Greek-English Lexicon, ed. by H.G. Liddell, R. Scott, and H.S. Jones

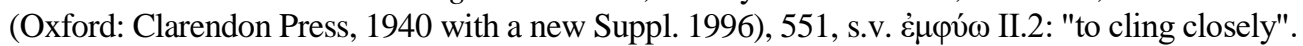

70. Kragelund, "Dreams", 55; contrary to that: Weber, Kaiser, 435 (referring to Plutarch). 
inconsistent with the writer's role image, ${ }^{71}$ Nicolaus lets Brutus make his point

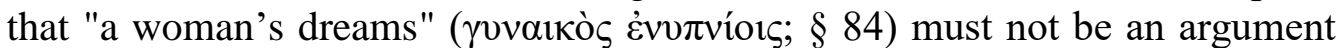
in political affairs. ${ }^{72}$ Nicolaus sketches a gender relationship of the husband's subordination to his wife and then criticises him because of it. The reaction of a third party expresses the author's view. With regard to the question asked at the end of the interim conclusion, his non-acceptance correlates with the woman's final failure.

\section{Velleius Paterculus (20/19 BC to circa AD 30)}

Velleius Paterculus covers the nightly appearance (nocturno visu) in his Historia Romana (Vell. 2.57.1f.; unless otherwise stated, all quotations from the chapter Vell. 2.57.2) that was presumably published around the year AD $30{ }^{73}$ Because of her nightmare, Calpurnia is said to have "kept begging him [Caesar] to remain at home on that day" (orabat, ut ea the domi subsisteret orabat) instead of going to the Senate. While other signs confirm that Calpurnia is right, Caesar ignores her warning (Vell. 2.57.1). ${ }^{74} \mathrm{He}$ is the only one who takes a decision. Accordingly, the question of gender hierarchy is clearly to be answered with a dominant position of the husband. The use of the weak verbal intervention mode orabat confirms the modified thesis. Velleius Paterculus criticises Caesar's ignorance by describing him "off his guard" (incautus, Vell. 2.57.1) and expresses his opinion on his behaviour towards the omen by an authorial comment here. I conclude, is another possible way a writer has to give his view about his protagonists' conduct. Although Velleius proves Calpurnia's vision right, along with Valerius he is the only author who does not even allow her a partial success in terms of the addressee's positive reaction. He shifts the failure of the intervention to the reaction of the addressee and, by doing so, shortens the radius of the female action in comparison to Nicolaus. The way Calpurnia behaves, hence, is not of the kind that it convinces Caesar to listen to her warning. In Velleius's short account about the prophecy, the wife takes action because she has been "terrified by a dream" (territa nocturno visu). ${ }^{75}$ In Nicolaus's report, in which Calpurnia is not successful either and in which her influence is not accepted, we see the same emotional behaviour ("terrified": $\delta \varepsilon \mu \alpha \tau \omega \theta \varepsilon i ̃ \sigma \alpha$, Nik. Dam. Aug., FGrHist 90 F $130 \S 83$ ). Thus, we need to examine how the other sources combine these elements.

71. Cf. Fischler, "Stereotypes", 120.

72. Cf. Kreck, Untersuchungen, 40, 46; Pelling, "Tragical Dreamer", 201.

73. Cf. Albrecht, Geschichte, II 897f.; Kragelund, "Dreams", 55 note 7; Ripat, "Omens", 169; M. Strothmann, "Calpurnia [1]," in Brill's New Pauly, Antiquity volumes, ed. by H. Cancik and H. Schneider, http://dx.doi.org/10.1163/1574-9347_bnp_e224970.

74. Ripat, "Omens", 169 claims that "Caesar, now better advised in greater specificity about his imminent demise, was understandably hesitant" but there is no evidence for this interpretation in Velleius Paterculus.

75. Concerning Calpurnia's fear cf. Weber, Kaiser, 433, 435. 


\section{Valerius Maximus (circa $20 \mathrm{BC}$ to AD 50)}

Valerius Maximus wrote his Facta et dicta memorabilia almost at the same time as Velleius, circa AD 30 (all subsequent quotations from Val. Max. 1.7.2). ${ }^{76}$ Because of her nightmare, Calpurnia begs Caesar, "to stay away from the Curia the next day" (ut proximo die curia se abstineret). He, however, goes to the Senate, "so that it does not seem, as if the dream of a woman had induced him to do so" (ne muliebri somnio motus id fecisse existimaretur). Calpurnia's intervention fails immediately due to the disregard of the addressee. Again, his reaction indicates that the author only allows for limited influence by a wife. She is not only unsuccessful but precisely because she is a woman. Valerius insistently claims that the female dream must not be an argument in political affairs. His nonacceptance, again, is mirrored in her failure so that, in the following sources, we have to examine, if this can be considered a constructing principle.

The gender relationship between Caesar and his wife is strictly hierarchical. Significantly, Valerius Maximus makes his qua sex powerless Calpurnia intervene not only exclusively by pleading rogare. She is even credited with an unceasing plea (rogare non destitisse) and yet is not given a hearing. ${ }^{77}$ Since the verbal mode of weak intensity is used, I regard this as another striking indication for my thesis that the intervention manners correlate with the gender hierarchy and represent the female options for acting. While Velleius says territa nocturno visu (Vell. 2.57.2), Valerius describes Calpurnia as "violently terrified" (vehementer exterritam). In Valerius's account, her emotional response is much more intense - and likewise his disapproval of her influence is stronger. Although a terrified female reaction to divine signs was a common topos, ${ }^{78}$ it should be noticed that neither Cicero nor Obsequens, both accepting Caecilia's action, mention any anxiety caused by her vision. On the contrary, as stated above, she is presented as the splendid counterexample to the matrons who could not restrain their drives. Therefore, ${ }^{79}$ the control of emotions seems to be a condition of acceptance so that affects like fright could be regarded as a marker for disapproval.

Plutarch of Chaironea (AD 45 to 120)

76. Cf. Albrecht, Geschichte, II 908f.; Kragelund, "Dreams", 55 note 7; Ripat, "Omens", 169; Strothmann, "Calpurnia", unpaged. English translation of Valerius Maximus's passages: A.K.R.

77. Cf. Kragelund, "Dreams", 55f.

78. The fearful reaction of women to divine signs is found in other stories as well, cf. for example Ripat, "Omens", 156; Scioli, "Dream Narrative", 229; K. Schnegg, Geschlechtervorstellungen und soziale Differenzierung bei Appian aus Alexandrien [Gender Concepts and Social Differentiation in Appian of Alexandria], Philippika 33 (Wiesbaden: Harrassowitz, 2010), 45f.

79. The meaning of affects is to be examined more closely within the $\mathrm{PhD}$ project. Some cases of female influence suggest that absence of affects does, the other way round, not always correlate with acceptable intervening, for example the legendary betrayal of the Roman citadel by Tarpeia in Flor. 1.1.12 or the operations of Marc Antony's wife Fulvia in Dio 48.4.1-4. In other passages, however, Dio ascribes hatred (" $\chi^{\prime} \theta \rho \alpha v$; LSJ, A Greek-English Lexicon, 748, s.v.

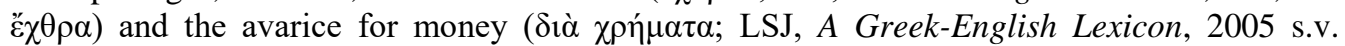
$\chi \rho \tilde{\eta} \mu \alpha)$ to her; cf. Dio 47.8.2. Nonetheless, in the cases in which affective emotionality is mentioned, it is connected with the author's disapproval. 
Plutarch's report at the beginning of the $2^{\text {nd }}$ century AD is the most detailed one (Plut. Caes. 63.8-12) ${ }^{80}$ He even describes the process of dreaming. ${ }^{81} \mathrm{By}$

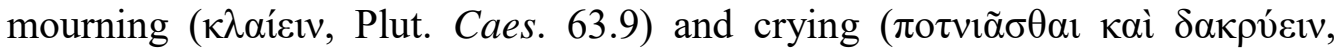
Plut. Caes. 63.9) Calpurnia has shown emotions already during her sleep. ${ }^{82}$ After awakening she intervenes by attempting to keep her husband back and is still "in a state of violent emotion" 83 ( $\pi \varepsilon \rho 1 \pi \alpha \theta 0$ õ $\sigma \alpha v$, Plut. Caes. 63.11). Caesar decides not to attend the Senate session,"[f]or never before had he perceived in

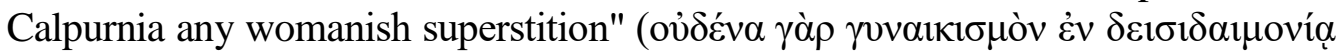

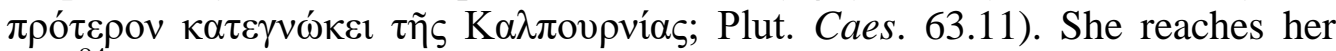
goal $^{84}$ in that very moment when she behaves like a woman is expected to, and in that very way which prevented her success in Valerius Maximus's report.

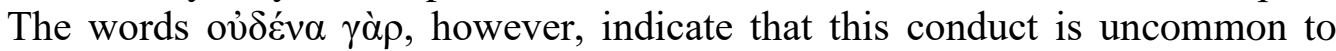
Caesar's wife. Plutarch twists the version of his predecessor in order to express his ideal: a wife should behave rovaıkı $\mu$ òv. ${ }^{85}$ His Calpurnia is the most restrained of all protagonists. With her weak verbal intervention - "she begged

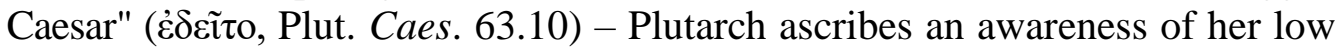
position against her husband to Calpurnia. She knows that her nightmare cannot be an argument in political affairs ("if it was possible, not to go out, but to postpone the meeting of the Senate; if, however, he had no concern at all for her dreams, she besought him to enquire by other modes of divination and by

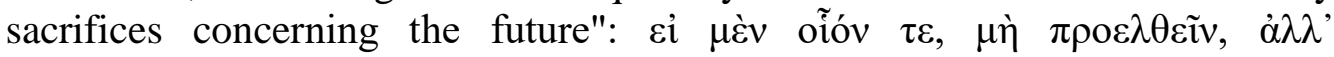

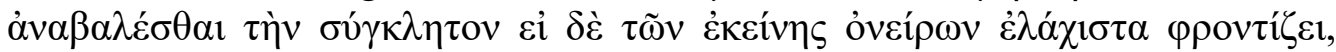

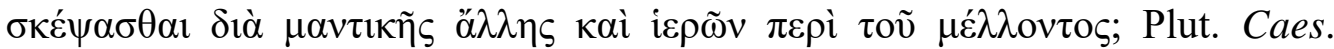
63.10) and tries not to be too demanding towards Caesar.

Acting correctly, thus, implies not to influence politics. The outcome of the story is analogous to Nicolaus of Damascus. Caesar goes to the Senate because Brutus has taunted him for making excuses with Calpurnia's dreams

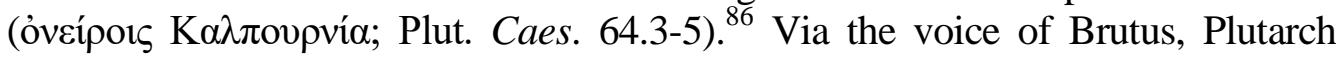
states that the entreaties of a wife cannot be enough to base political decisions. On

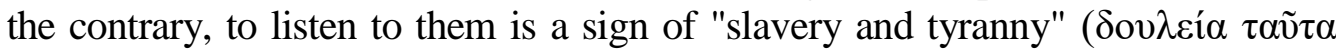

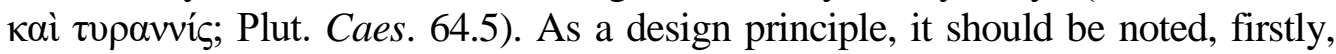
that a feedback of two stages indicates the range of the intervention: 1) the reaction of the addressee, which mirrors the gender hierarchy and 2) the reaction of society which mirrors the author's attitude. Secondly, non-acceptance

80. Cf. ibid., 55 note 7; Ripat, "Omens", 170; Strothmann, "Calpurnia", unpaged.

81. Concerning Plutarch's interest in dreams and his opinion about their truthfulness, cf. B. Näf, Traum und Traumdeutung im Altertum [Dream and Dream Interpretation in Antiquity] (Darmstadt: Wissenschaftliche Buchgesellschaft, 2004), 103-106.

82. Cf. Weber, Kaiser, 434. Scioli states in a different context that "lamenting and weaving, both [are] non-verbal modes of expression", Scioli, "Dream Narrative", 233. Although, like in Obsequens's report, female actions could be placed in dreams, Calpurnia's weeping is not yet her political intervention.

83. Cf. LSJ, A Greek-English Lexicon, 1381, s.v. $\pi \varepsilon \rho \imath \pi \alpha \theta \dot{\varepsilon} \omega$.

84. Cf. Weber, Kaiser, 435.

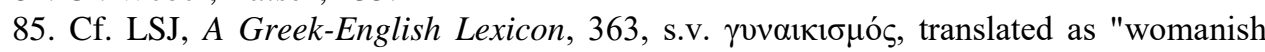
weakness".

86. Cf. Kragelund, "Dreams", 55. 
correlates both with Calpurnia's failure and, once more, with the high degree of her emotional involvement. Strikingly, her emotional state is equated with

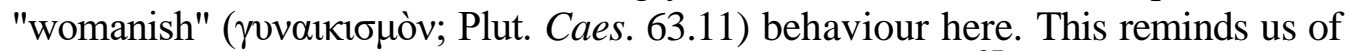
Hänninen's hypothesis, women had to adopt a "masculine" ${ }^{17}$ conduct in order to be able to operate successfully in affairs with political connotation. ${ }^{88}$ Looking from this perspective on Plutarch's Caesar who "was in some suspicion and

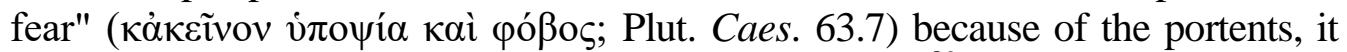
seems likely that he, as a consequence for his "female" 89 acting, is criticised for his emotive state of mind, too. Thus, political acting in general - disregarding gender- had to be freed from affective emotions. ${ }^{90}$

\section{Suetonius Tranquillus (AD 70 to 122)}

In the early $120 \mathrm{~s} \mathrm{AD}$, Suetonius published his Life of the Caesars. ${ }^{91} \mathrm{He}$ lists Calpurnia's dream amongst numerous prophecies of Caesar's assassination (Suet. Iul. 81.3) (92 $^{92}$ afterwards, he states: "Both for these reasons and because of poor health he hesitated for a long time whether to stay at home and put off what he had planned to do in the senate" (Ob haec simul et ob infirmam valitudinem diu cunctatus an se contineret et quae apud senatum proposuerat agere differret; Suet. Iul. 81.4). Suetonius does not describe the intervention. As in Cicero, it can be concluded that Calpurnia had informed Caesar about her dream because he could only have hesitated $o b$ haec $^{93}$ unless she had let him know its content. There is no clue with regard to the intensity of the mode. The hierarchical relationship is also difficult to grasp because, in contrast to Cicero, no obvious reference is made to a male execution of a female initiated political task. Therefore, no insistent gender discourse can be detected.

Compared to Cicero once more, we only see the result of Calpurnia's influence in the addressee's reaction. As in Nicolaus of Damascus and Plutarch,

87. Hänninen, "Caecilia Metella", 38. With regard to a women's male male behavior Fulvia, wife of M. Antonius, comes to mind first, cf. Dettenhofer, "Frauen", 149; C. Virlouvet, "Fulvia the Woman of Passion," in Roman Women, ed. by A. Fraschetti, transl. by L. Lappin, 66-81 (Chicago: Univ. of Chicago Press, 2001), 75-80. Regarding criticism on Fulvia for behaving like a man: Kreck, Untersuchungen, 212.

88. Cf. ibid. (concerning the case of Caecilia); and also Dettenhofer, "Frauen", 149.

89. Contrary to that: Schnegg, Geschlechtervorstellungen, $45 \mathrm{f}$.

90. The word 'affective' is to stress here, since especially Flaig has shown that emotions were not always affective, but, like the squalor, were a frequently used tool in Roman politics, cf. E. Flaig, Ritualisierte Politik. Zeichen, Gesten und Herrschaft im Alten Rom [Ritualised Politics. Symbols, Gestures, and Power in Ancient Rome] (Göttingen: Vandenhoeck \& Ruprecht, 2003), $106,120-122$. The female weakness and emotionality is most clearly discussed by the ancient authors within their depiction of legendary exempla, cf. for example G. B. Miles, "The First Roman Marriage and the Theft of the Sabine Women," in Innovations in Antiquity, ed. by R. Hexter and D. Selden, 161-196 (London: Routledge, 1992), 182, 184, 187. Miles explicitely refers to "the problem of passions" as a problem of Rome's well-being, ibid., 184.

91. Cf. Albrecht, Geschichte, II 1192f.

92. Cf. Kragelund, "Dreams", 55 note 7; Ripat, "Omens", 170f.; Strothmann, "Calpurnia", unpaged.

93. These two words for certain refer to all signs mentioned but this does not change this interpretation. 
the wife attains success. Significantly, she is no longer characterised as terrified. One might think that her reaction to the dream has merely been omitted by Suetonius together with the intervention. It is conspicuous, however, that even the statement that a woman's dream is not supposed to be an argument, is no longer ascribed to Brutus. Instead, the latter changes Caesar's mind by using the argument "not to disappoint the full meeting which had for some time been waiting for him" (ne frequentis ac iam dudum opperientis destitueret; Suet. Iul. 81.4). Again, no positioning to a gender discourse is discernible. In view of the positive reaction of the addressee, the lack of a negative reaction of society embodied by Brutus and the absence of any critical authorial utterances, I conclude that Suetonius accepted the wife's success. For the ascription of affective behaviour is missing, it reaffirms the thesis according to the affects which mark the author's disapproval of an intervention. Although the action of Suetonius's Calpurnia does not reach its goal anyway, the failure is not used as an occasion to stress gender role ideals. Thus, success or failure has nothing to do with the acceptance of female political influence.

\section{Appian of Alexandria (AD 90 to 160)}

Appian discusses the assassination of Caesar as part of his books on the civil wars of his Roman History (App. civ. 2,115, all subsequent quotations from this chapter). ${ }^{94} \mathrm{He}$ describes Calpurnia's intervention with the words:

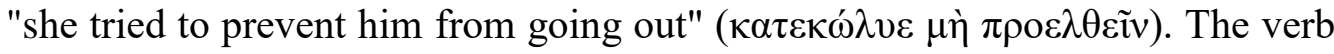
$\kappa \alpha \tau \alpha \kappa \omega \lambda \hat{v} \omega$ is vague concerning the mode. Other examples given by LSJ hardly help with the classification. ${ }^{95}$ Accordingly, the verb can be classified into strong verbal, ${ }^{96}$ weak non-verbal, ${ }^{97}$ as well as strong non-verbal. ${ }^{98}$ On the basis of LSJ, a weak verbal intervention can be excluded so that a certain appreciation of the female position in the gender relationship can be imagined. In order to underpin or disprove this assumed relationship, there is hardly any further evidence in the paragraph. Although Appian specifies other prophecies that con-

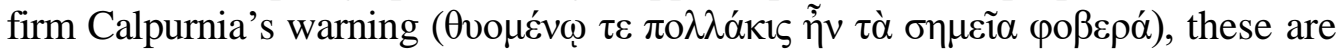
not portents classified as expressions of the fact that the wife's intervention for

94. Cf. Kragelund, "Dreams", 55 note 7. Ripat, "Omens", 171 lists several omens of Caesar's assassination in Appian but does not mention the dream of Calpurnia.

95. Cf. LSJ, A Greek-English Lexicon, 897, s.v. $\kappa \alpha \tau \alpha \kappa \omega \lambda v ́ \omega$, tanslated imprecise regarding the quality: "hinder from doing, [...] detain, keep". The examples come from Greek Antiquity and are not related to female actions.

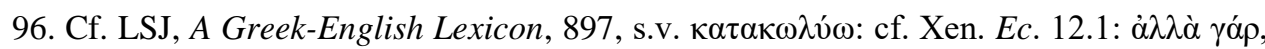

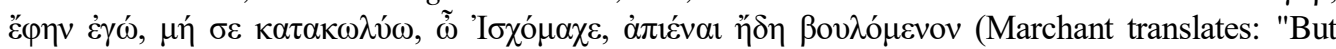
perhaps I am keeping you, Ischomachus,' I continued, 'and you want to get away now?"); cf. also

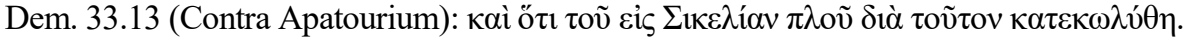

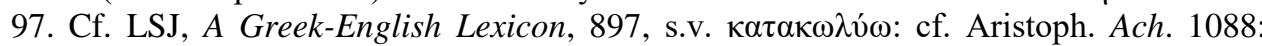
$\delta \varepsilon ı \pi v \varepsilon \tilde{\imath} v \kappa \alpha \tau \alpha \kappa \omega \lambda v ́ \varepsilon 1 \varsigma \pi \alpha ́ \lambda \alpha 1$ (Henderson translates: "you've held up dinner a long time", in fact, this does not describe an intended action directed to an addressee); cf. also Dem. 53.5 (Contra

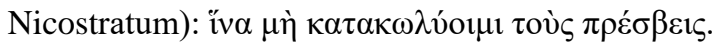

98. Cf. LSJ, A Greek-English Lexicon, 897, s.v. $\kappa \alpha \tau \alpha \kappa \omega \lambda \nu ́ \omega:$ cf. Xen. Anab. 5.2.16: $\kappa \alpha \tau \varepsilon \kappa \omega ́ \lambda v \sigma \varepsilon \tau \tilde{\omega} \nu$ ó $\pi \lambda \imath \tau \tilde{\omega} \nu \check{\varepsilon} \xi \omega$ (Brownson translates: "kept out as many as he could of the hoplites"); cf, also Dem. 53.5 (see note above). 
Caesar is not enough to base his decision on as it was the case in Plutarch (cf. Plut. Caes. 63.10). In Appian a devaluation of her omen is missing.

On the contrary, his Caesar wants to dismiss the Senate. Calpurnia has a partial success. It is Brutus again who "persuaded him, in order not to incur the charge of disregard for the Senate, to go there and dismiss it himself" ("̈ $\pi \varepsilon 1 \sigma \varepsilon \mu \eta$

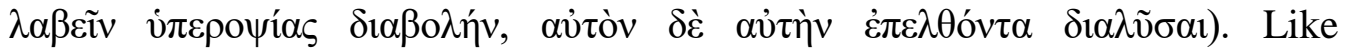
Suetonius, Appian thinks that a wife's dream can be an argument in political affairs. In addition, there is no negative assessment of the female interference. Hence, I conclude that Appian accepts the woman's intervention in the very way he describes it. ${ }^{99}$ Although the other signs are characterised as "fearful" 100 ( $\varphi$ $\beta \varepsilon \rho \alpha)$, this attribute does not refer to Calpurnia's conduct. There is no evidence of an action motivated by affect, which, once again, supports the assumption that a wife's successful influence in politics could be accepted only as long as she exercised control over her affects. As in Suetonius, Calpurnia does not reach her goal in Appian's account but the final failure is in no way linked to reasons of gender. Even unsuccessful interventions could have been accepted.

\section{Cassius Dio (AD 155 to 253) and Julius Obsequens $\left(2^{\text {nd }}\right.$ Half of the $4^{\text {th }}$ Century AD)}

As already indicated, the two remaining authors, Cassius Dio (Dio 44.17.2) and Obsequens (Obs. 67), only mention Calpurnia's dream. ${ }^{101}$ An intervention is not even implicitly contained so that the indicators cannot be examined any further. In his Roman History, written before AD 229, Cassius Dio presents a long list of omens in regard to Caesar's assassination. ${ }^{102}$ He reduces the episode to the character of one divine sign amongst many. The de-individualisation of the female protagonist (Dio 44.17.2) is noteworthy for all the earlier authors have mentioned the name of Calpurnia. Cassius Dio gives the

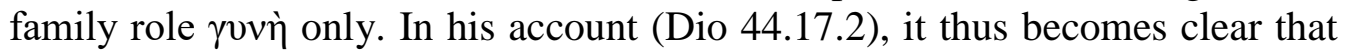
the relationship between husband ( $\tau$ òv ö $v \delta \rho \alpha$ ) and wife ( with the case of Calpurnia, but Dio does not continue to contribute to this discourse. Obsequens is the only author to mention both the dreams of Caecilia and Calpurnia. ${ }^{103}$ In Late Antiquity, he cites two portents for the Caesar's assassination (Obs. 67) crediting much more attention to Calpurnia's nightmare than to the second omen. It is striking that he describes the woman as Calpurnia uxor (Obs. 67) while omitting the family role concerning Metella Caecilia (Obs. 55). This observation confirms that Obsequens has not omitted the reference to the family role in general but only because he, in his portrayal of Caecilia, was not interested in the female relation to a man but in the behaviour of the matrons. ${ }^{104}$

99. Cf. Schnegg, Geschlechtervorstellungen, 73, 91.

100. Cf. LSJ, A Greek-English Lexicon, 1946, s.v. poßepós.

101. Cf. Hänninen, "Caecilia Metella", 34; Kragelund, "Dreams", 55 note 7; Ripat, "Omens",

171; Strothmann, "Calpurnia", unpaged.

102. Concerning Dio's version of Calpurnia's dream cf. Weber, Kaiser, 433. With regard

to Dio's interest in dreams cf. Näf, Traum und Traumdeutung, $110 \mathrm{f}$.

103. Cf. Hänninen, "Caecilia Metella", 34.

104. Cf. ibid., 36-38; Kragelund, "Dreams", 59; Schultz, "Juno Sospita", 221. 
Whereas the dream belonged to the narrative of Caesar's murder since Nicolaus of Damascus, ${ }^{105}$ this did not apply to Calpurnia's reaction. According to Kragelund, in the case of the assassination, the ending of the story was "obvious[ly]"106 not the author's sole concern but the unchangeable core of the narrative. ${ }^{107}$ This outcome explains why Calpurnia's exertion of influence had to fail in the accounts of Suetonius and Appian despite their acceptance of her intervention: The narrative required her failure and also a reason for it. Even though other versions of the episode already existed, a writer would not have necessarily attributed the failure to gender role images, if he saw no need to discuss these. Finally, the investigation of the two cases confirms that the sources reflect the author's opinion concerning gender discourse.

\section{Conclusion}

The sources for Caecilia and Calpurnia demonstrate that dreams as divine signs were regarded as a factor which caused and legitimised female agency from the late Republic to Late Antiquity. The study of the two cases proves that the form and emphasis by which ancient authors discuss gender role ideals, relations, and hierarchies vary widely. There seems to be a decline of the gender discourse in the case of Julius Caesar's uxor Calpurnia. It can already be observed in Suetonius and Appian and continues in the reports of Dio and Obsequens in which the female intervention disappears from the narrative. Conversely, compared to Cicero who wrote in the late Republic, the discussion on female virtues becomes more intense in Obsequens's report, that is in Late Antiquity. Despite these differences in terms of content, recurring patterns are recognisable.

The family role indicates the particular gender relationship referred to. In our sources, this role has been omitted where the report deals with the conduct of women rather than with a male-female-relationship. On the basis of one text alone, conclusions can only be drawn towards the specific relations nominated by the family role mentioned in the source. If Cicero accepts the initiative of a filia, nothing can be said about whether this is true for all women.

With regard to the intervention, the "mode[s] of communication" ${ }^{108}$ can be considered the indicator of gender hierarchy as well as the associated options of action the woman has towards her addressee. Two modes, verbal and nonverbal, need to be distinguished. Both are displayed in two degrees of intensity, weak and strong. The strong non-verbal mode exposes wide options to act and the most revaluated position in the gender hierarchy. A narrow action repertoire is mirrored by the weak verbal mode. In between, the strong verbal as well as the weak non-verbal manner is located. Using these modes of intervention, ancient authors shape gender relations and role images. The

105. Cf. Harris, Dreams, 91.

106. Kragelund, "Dreams", 55.

107. Cf. ibid.; Ripat, "Omens", 167f.

108. Scioli, "Dream Narrative", 208. 
ascription of partial success or direct failure in regard to the reaction of the addressee draws a certain relationship between man and woman.

On the contrary, failure does not signify a lack of an ancient writer's consent, nor does success automatically correlate with acceptance. Success and failure, therefore, are no indicators of the author's agreement to the female interference. The outcome of the story is not his decision but part of the narrative expected by the reader. The author has different ways to express his opinion. Besides explicit commentaries, he can judge the intervention via the reaction ascribed to society. Furthermore, the attribution of affective emotionality to the woman indicates the author's lack of agreement. He accepts her influence only if her actions are not controlled by emotions.

This investigation has established an analysis scheme which aims to answer the following questions: 1) Which particular gender relationship or gender role does the writer comment on? 2) How does the hierarchical relationship discussed look like? 3) How does the author judge that? All authors use the same patterns which they put together individually like building blocks so that their attitude to the gender discourse is expressed. The literary approach to the sources provides a method which I would like to use now for a further comparison of the different authors regarding the depicted gender relationships and the female scope for action. The model serves as a first step for examining the female political interventions of the late Roman Republic more systematically.

\section{Acknowledgements}

I would like to thank Prof. Dr. Christiane Kunst, Assoc.-Prof. Dr. Ralph Haeussler, Dr. Maik Patzelt, Sebastian Bondzio, Isabelle Bosch, Tim Helmke, Carolin Schneider, Anne Südbeck, and Sonja Wibben for their support.

\section{Bibliography}

\section{Sources}

Appian. Appian's Roman History. In Four Volumes, Vol. III: The Civil Wars Books 13.26, with an Engl. transl. by H. White. First published 1913, reprinted London et al.: Heinemann, 1979 (Loeb Classical Library; 4).

Aristophanes. Acharnians. Knights, with an Engl. transl. by J. Henderson. Cambridge et al.: Harvard Univ. Press, 1998 (Loeb Classical Library; 178).

Cassius Dio. Dio's Roman History. In Nine Volumes, Vol. IV: Books 41-45, with an Engl. transl. by E. Cary on the basis of the version of H. B. Foster. First published 1916, reprinted Cambridge et al.: Harvard Univ. Press, 1969 (Loeb Classical Library; 66).

Cicero. De senectute. De amicitia. De divinatione, with an Engl. transl. by W. A. Falconer. First published 1923, reprinted London et al.: Heinemann et al., 1979 (Loeb Classical Library; 154). 
Demosthenes, Vol. IV: Private Orations: XXVII-XL, with an Engl. transl. by A.T. Murray. Cambridge et al.: Harvard Univ. Press et al., 1965 (Loeb Classical Library; 318); Vol. VI: Private Orations: L-LVIII. - In Neaeram: LIX, with an Engl. transl. by A.T. Murray. Cambridge et al.: Harvard Univ. Press et al., 1978 (Loeb Classical Library; 351).

FGrHist. Die Fragmente der griechischen Historiker [The Fragments of the Greek Historians], Vol. II: Zeitgeschichte, A: Universalgeschichte und Hellenika: Nr. 64-105, edited by F. Jacoby. First published 1926, reprinted Berlin et al.: Weidmann, 1961.

Livy. T. Livi ab urbe condita libri, Vol. IV: Libri XLI-XLV, edited by W. Weissenborn and M. Mueller - Periochae omnium librorum. Fragmenta Qxyrynchi reperta. Iulii Obsequentis Prodigiorum liber, edited by O. Rossbach. Stuttgart: Teubner 1959 (Bibliotheca scriptorium Graecorum et Romanorum Teubneriana).

Nicolaus of Damascus. Nicolaus of Damascus' Life of Augustus. A Historical Commentary Embodying a Translation, edited by C. M. Hall. First published 1923, reprinted Ann Arbor: University Microfilms International, 1980 (Smith College Classical Studies; 4).

Plutarch. Plutarch's Lives. In Eleven Volumes, Vol. VII: Demosthenes and Cicero. Alexander and Caesar, with an Engl. transl. by B. Perrin. First published 1919, reprinted London et al.: Heinemann, 1971 (Loeb Classical Library; 99).

Suetonius. Suetonius. In Two Volumes, Vol. I, with an Engl. transl. by J. C. Rolfe. First published 1913, reprinted Cambridge et al.: Harvard Univ. Press, 1979 (Loeb Classical Library; 31).

Valerius Maximus. Valeri Maximi facta et dicta memorabilia, Vol. 1: Libri I-VI, edited by J. Briscoe. Stuttgart et al.: Teubner 1998 (Bibliotheca scriptorium Graecorum et Romanorum Teubneriana).

Velleius Paterculus. Compendium of Roman History, with an Engl. transl. by F. W. Shipley. London: Heinermann, 1967 (Loeb Classical Library; 152).

Xenophon. Xenophon in Seven Volumes, Vol. III: Anabasis, with an English transl. by C.L. Brownson. First published 1922, reprinted Cambridge et al.: Harvard Univ. Press, 1992 (Loeb Classical Library; 90); Vol. IV: Memorabilia and Oeconomicus, with an Engl. transl. by E.C. Marchant - Symposium and Apology, with an Engl. transl. by O.J. Todd. First published 1923, reprinted Cambridge et al.: Harvard Univ. Press, 1979 (Loeb Classical Library; 168).

\section{Literature}

Albrecht, M. von Geschichte der römischen Literatur. Von Andronicus bis Boethius, mit Berücksichtigung ihrer Bedeutung für die Neuzeit [History of Roman Literature. From Andronicus to Boethius, Taking into Account Their Importance for Modern Times]. 2 Vol. Berlin: de Gruyter, 2012.

Corbeill, A. "Dreams and the Prodigy Process in Republican Rome." In Sub imagine somni: Nightmare Phenomena in Greco-Roman Culture, edited by E. Scioli and C. Walde, 81-101. Pisa: Ed. ETS, 2010.

Dettenhofer, M.H. "Frauen in politischen Krisen. Zwischen Republik und Prinzipat. [Women in Political Crises. Between Republic and Principate]." In Reine Männersache? Frauen in Männerdomänen der antiken Welt, edited by M.H. Dettenhofer, 133-157. Cologne: Böhlau, 1994.

Dixon, S.A. Reading Roman Women: Sources, Genres, and Real Life. London: Duckworth, 2007. 
Eder, W. "Curia". In Brill's New Pauly, Antiquity volumes, edited by H. Cancik and H. Schneider. http://dx.doi.org/10.1163/1574-9347_bnp_e12220940.

Evans, J.K. War, Women and Children in Ancient Rome. London: Routledge, 1991.

Finley M.I. Aspects of Antiquity. Discoveries and Controversies. Harmondsworth: Penguin Books, 1978.

Fischler, S. "Social Stereotypes and Historical Analysis: The Case of the Imperial Women at Rome." In Women in Ancient Societies. 'An Illusion of the Night', edited by L.J. Archer, S. Fischler, and M. Wyke, 115-133. Basingstoke: Macmillan, 1994.

Flaig, E. Ritualisierte Politik. Zeichen, Gesten und Herrschaft im Alten Rom [Ritualised Politics. Symbols, Gestures, and Power in Ancient Rome]. Göttingen: Vandenhoeck \& Ruprecht, 2003.

Graf, F. "Anna Perenna". In Brill's New Pauly, Antiquity volumes, edited by H. Cancik and H. Schneider. http://dx.doi.org/10.1163/1574-9347_bnp_e122270.

Hallett, J.P. Fathers and Daughters in Roman Society. Women and the Elite Family. Princeton: Princeton Univ. Press, 1984.

Hänninen, M.-L. "The Dream of Caecilia Metella. Aspects of Inspiration and Authority in Late Republican Roman Religion." In Female Networks and the Public Sphere in Roman Society, edited by P. Setälä and L. Savunen, 29-38. Rome: Institutum Romanum Finlandiae, 1999.

Harris, W.V. "Roman Opinions about the Truthfulness of Dreams." JRS 93 (2003), 1834.

Harris, W.V. Dreams and Experience in Classical Antiquity. Cambridge: Harvard Univ. Press, 2009.

Hermes, L. Traum und Traumdeutung in der Antike [Dream and Dream Interpretation in Antiquity]. Zurich: Artemis \& Winkler, 1996.

Höcker, C. "Theatrum Pompei(i)." In Brill's New Pauly, Antiquity volumes, edited by H. Cancik and H. Schneider. http://dx.doi.org/10.1163/1574-9347_bnp_e1207070.

Kierdorf, W. "Senatus." In Brill's New Pauly, Antiquity volumes, edied by H. Cancik and H. Schneider. http://dx.doi.org/10.1163/1574-9347_bnp_e1108330.

Kraemer, R.S. Her Share of the Blessings. Women's Religions among Pagans, Jews, and Christians in the Greco-Roman World. Oxford: Oxford Univ. Press, 1992.

Kragelund, P. "Dreams, Religion, and Politics in Republican Rome." Historia 50, no. 1 (2001), 53-95.

Kreck, B. Untersuchungen zur politischen und sozialen Rolle der Frau in der späten römischen Republik [Studies on Women's Political and Social Role in the Late Roman Republic]. Marburg, 1975.

LSJ: A Greek-English Lexicon, edited by H.G. Liddell, R. Scott, and H.S. Jones. Oxford: Clarendon Press, 1940, with a new Suppl. 1996.

MacAlister, S. "Gender as Sign and Symbolism in Artemidoros: Social Aspirations and Anxieties." Helios 19 (1992), 140-160.

Mastrocinque, A. Bona Dea and the Cults of Roman Women. Potsdamer Altertumswissenschaftliche Beiträge 49. Stuttgart: Steiner, 2014.

Meister, K. "Nicolaus [3]." In Brill's New Pauly, Antiquity volumes, edited by H. Cancik and H. Schneider. http://dx.doi.org/10.1163/1574-9347_bnp_e822620.

Miles, G. B. "The First Roman Marriage and the Theft of the Sabine Women." In Innovations in Antiquity, edited by R. Hexter and D. Selden, 161-196. London: Routledge, 1992.

Münzer, F. "Caecilius [135]." In RE III.1 (1897), 1235.

Näf, B. Traum und Traumdeutung im Altertum [Dream and Dream Interpretation in Antiquity]. Darmstadt: Wissenschaftliche Buchgesellschaft, 2004. 
Pelling, C. "Tragical Dreamer: Some Dreams in the Roman Historians." $G \& R$ 44, no. 2 (1997), 197-213.

Rawson, E. "Religion and Politics in the Late Second Century B.C. at Rome." Phoenix 28.2 (1974), 193-212.

Ripat, P. "Roman Omens, Roman Audiences, and Roman History." $G \& R$ 53, no. 2 (2006), 155-174.

Rives, J.B. Religion in the Roman Empire. Malden: Blackwell Publishing, 2007.

Rosenberger, V. Gezähmte Götter. Das Prodigienwesen der römischen Republik [Tamed Gods. The Prodigy Process in Republican Rome]. Heidelberger Althistorische Beiträge und epigraphische Studien 27. Stuttgart: Steiner, 1998.

Scardigli, B. "Die Frau im Prodigienwesen der römischen Republik [Women in the Prodigy Process in Republican Rome]." In Egypte - Grèce - Rome. Les différents visages des femmes antiques; travaux et colloques du séminaire d'épigraphie grecque et latine de l'IASA 2002-2006, edited by F. Bertholet Anne Bielman Sanchez and Regula Frei-Stolba, 197-221. Echo 7. Bern: Peter Lang AG, 2008.

Scheid, J. An Introduction to Roman Religion, transl. by Janet Lloyd. Edinburgh: Edinburgh Univ. Press, 2003.

Schmidt, P.L. Iulius Obsequens und das Problem der Livius-Epitome. Ein Beitrag zur Geschichte der lateinischen Prodigienliteratur [Julius Obsequens and the Problem of the Livy Epitomes. A Contribution to the History of the Latin Literature on Prodigies]. Abhandlungen der Geistes- und Sozialwissenschaftlichen Klasse 5. Wiesbaden: Steiner, 1968.

Schnegg, K. Geschlechtervorstellungen und soziale Differenzierung bei Appian aus Alexandrien [Gender Concepts and Social Differentiation in Appian of Alexandria]. Philippika 33. Wiesbaden: Harrassowitz, 2010.

Schultz, E. "Juno Sospita and Roman Insecurity in the Social War." In Religion in Republican Italy, edited by C.E. Schultz and P.B. Harvey, 207-277. Classical Studies; 33. Cambridge: Cambridge Univ. Press, 2001 Yale.

Scioli, E. "The Dream Narrative as a Mode of Female Discourse in Epic Poetry." TAPhA 140, no. 1 (2010), 195-238.

Scullard, H.H. Festivals and Ceremonies of the Roman Republic. Ithaka: Cornell Univ. Press, 1981.

Späth, T. Männlichkeit und Weiblichkeit bei Tacitus. Zur Konstruktion der Geschlechter in der römischen Kaiserzeit [Masculinity and Femininity in Tacitus. Constructing Gender of the Sexes in the Roman Empire]. Geschichte und Geschlechter 9. Frankfurt a. M. et al.: Campus-Verlag, 1994.

Strothmann, M. "Calpurnia [1]." In Brill's New Pauly, Antiquity volumes, edited by H. Cancik and H. Schneider. First published online 2006. DOI $=$ http://dx.doi. org/10.1163/1574-9347_bnp_e224970.

Takács, S.A. Vestal Virgins, Sibyls, and Matrons. Women in Roman Religion. Austin: Univ. of Texas Press, 2008.

Treggiari, S. Terentia, Tullia und Publilia: The Women of Cicero's Family. Women of the Ancient World. London: Routledge, 2007.

Vaschide, N. and Piéron, H. "Prophetic Dreams in Greek and Roman Antiquity." The Monist 11.2 (1901), 161-194.

Virlouvet, C. "Fulvia the Woman of Passion." In Roman Women, edited by A. Fraschetti, transl. by L. Lappin, 66-81. Chicago: Univ. of Chicago Press, 2001.

Walde, C. "Explorationen: Schlaf - Traum - Traumdeutung und Gender in der griechisch-römischen Antike" ["Explorations: Sleep - Dream - Dream Interpretation and Gender in Greco-Roman Antiquity"]. In Gender Studies in den 
Altertumswissenschaften: Schlaf und Traum, edited by C. Walde and G. Wöhrle, 140. IPHIS 6. Trier: Wissenschaftlicher Verlag Trier, 2014.

Wardle, D. "The Sainted Julius: Valerius Maximus and the Dictator." $C P h$ 92, no. 4 (1997), 323-345.

Wardman, A. Religion and Statecraft among the Romans. Baltimore: JHU Press, 1982.

Weber, G. Kaiser, Träume und Visionen in Prinzipat und Spätantike [Emperors, Dreams and Visions in Principate and Late Antiquity]. Historia. Einzelschriften 143. Stuttgart: Steiner, 2000. 
